\title{
Feature selection in Enose applications
}

\author{
Thomas Nowotny ${ }^{1,2^{*}}$, Amalia Z Berna ${ }^{2}$, Russell Binions ${ }^{3}, X_{\text {Rosalind Wang }}^{4}$, Joseph T Lizier ${ }^{4}$, Mikhail Prokopenko ${ }^{4}$, \\ Stephen Trowell ${ }^{2}$
}

From 1st International Workshop on Odor Spaces
Hannover, Germany. 4-7 September 2013

In my presentation I will summarise results for feature selection from a number of Enose applications ranging from general chemical classification and breath analysis with metal-oxide based Enoses to work scoping the use of biological receptors, in particular receptors of the fruit fly Drosophila, for applications in wine making and explosives detection. The common thread in all applications is the availability of high-dimensional data which is often noisy and in all of its details not necessarily very information rich for any particular application. The challenge for building useful classification systems is to define, extract and select the most "informative" features from the highdimensional data. I will give an overview over our work using exhaustive "wrapper" approaches and a brief comparison to information-theory based methods. I will conclude by highlighting the most pertinent open questions encountered in this research area.

\footnotetext{
Authors' details

'CCNR, School of Engineering and Informatics, University of Sussex, Falmer, Brighton BN1 9QJ, UK. ${ }^{2}$ CSIRO Ecosystem Sciences and Food Futures Flagship, GPO Box 1700 Canberra, ACT 2601, Australia. ${ }^{3}$ School of Engineering and Materials Science, Queen Mary University of London, London E1 4NS, UK. ${ }^{4} \mathrm{CSIRO}$ Information and Communications Technologies Centre, PO Box 76, Epping, NSW 1710, Australia.
}

Published: 16 April 2014

Submit your next manuscript to BioMed Central and take full advantage of:

- Convenient online submission

- Thorough peer review

- No space constraints or color figure charges

- Immediate publication on acceptance

- Inclusion in PubMed, CAS, Scopus and Google Scholar

- Research which is freely available for redistribution
() Biomed Central

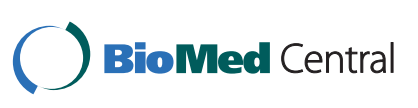

